Available online at GSC Online Press Directory

GSC Biological and Pharmaceutical Sciences

e-ISSN: 2581-3250, CODEN (USA): GBPSC2

Journal homepage: https://www.gsconlinepress.com/journals/gscbps

(RESEARCH ARTICLE)

\title{
Evaluation of potential lactic acid bacteria single starter cultures for production of traditional Ivoirian cereal beverages
}

\author{
Aka Solange 1, 2, ${ }^{*}$, Tano Brou Marcellin ${ }^{1,}$ Kouakou-Kouamé Amenan Clémentine ${ }^{1}$ and Koussemon-Camara \\ Marina ${ }^{1}$ \\ ${ }_{1}$ Science and Food Technology Unit, University Nangui Abrogoua, Côte d'Ivoire. \\ ${ }^{2}$ Centre Suisse de Recherches Scientifiques en Côte d'Ivoire (CSRS), BP 1303 Abidjan 01, Côte d'Ivoire.
}

Publication history: Received on 06 May 2020; revised on 20 May 2020; accepted on 20 May 2020

Article DOI: https://doi.org/10.30574/gscbps.2020.11.2.0129

\begin{abstract}
Twenty-three lactic acid bacteria (LAB) previously isolated from tchapalo process were evaluated as single starter cultures for traditional Ivoirian beverages production. These LAB were inoculated separately into sorghum wort and fermented at $30^{\circ} \mathrm{C}$ for $12 \mathrm{~h}$. During fermentations, $\mathrm{pH}$, titratable acidity, and LAB growth were determined. After that, the six better bacteria had been used to produce controlled sour wort, sweet wort and tchapalo. Then, $\mathrm{pH}$, titratable acidity, total soluble solids, and organic acids were analyzed. Their antimicrobial activities also were tested. Within $6 \mathrm{~h}$ of fermentation, out of twenty-three bacteria, only six (26.08\%) of strains namely L. fermentum strains $\mathrm{S}_{6}, \mathrm{~S}_{42}$ and $\mathrm{S}_{45}, P$. acidilactici strains $\mathrm{S}_{7}$ and $\mathrm{S}_{52}$ and $P$. pentosaceus strain $\mathrm{S}_{5}$ accelerated fermentation by dropping of $\Delta \mathrm{pH}$ to $\geq 1.5$ units and increasing of $\Delta \mathrm{AT}$ to $\geq 0.15 \%$. Lactobacillus fermentum strain $\mathrm{S}_{6}$ carried out his exponential growth rate from 0.18 log $\mathrm{CFU} / \mathrm{mL}$ to $2.67 \log \mathrm{CFU} / \mathrm{mL}$ during 2 to $6 \mathrm{~h}$. The sour wort obtained by using of these strains were like those of controls. Tartaric and lactic acids were detected in all the fermented beverages with single starter cultures with a predominance of lactic acid, but their contents varied according to starter cultures. Some sweet wort and tchapalo produced with single starter cultures were able to inhibit the growth of Escherichia coli, Salmonella typhi and Staphylococcus aureus. These six LAB would be used single to improve safety of sweet wort and tchapalo.
\end{abstract}

Keywords: Lactic acid bacteria; Starter cultures; Fermentation; Sorghum wort; Sweet wort; Tchapalo

\section{Introduction}

Sorghum is an important cereal in Africa regions. Most of this staple, produced in Côte d'Ivoire or imported from neighboring countries, is used to produce tchapalo, a traditional cloudy beer containing suspended solids and yeast [1, 2]. This traditional beverage is obtained from alcoholic fermentation of sweet wort. The sweet wort, which is a nonalcoholic beverage, is obtained by spontaneous lactic fermentation and/or back-slopping of the sweet wort [3, 4]. Sweet wort is generally consumed by women, infants, children, and non-alcoholic consumers. Both beverages have nutritional values helping to improve the diet of consuming populations. In addition, therapeutic properties are attributed to them because of their laxative, antimalarial and anti-hemorrhoidal properties [4-6].

The production of tchapalo and sweet wort originate from Northern Côte d'Ivoire and are mainly produced by women. These women have now made it a real economic activity generating income in all areas of the country and particularly in Abidjan, the economic capital [3, 5, 6]. Unfortunately, tchapalo and sweet wort are often produced under poor hygienic conditions with rudimentary equipment, tedious and costly operations, and the use of unselected dried traditional yeasts from previous alcoholic fermentations. The spontaneous fermentation also depends of environmental

\footnotetext{
* Corresponding author: Aka Solange phone: +22505716832 E-mail adress: solangeakan@yahoo.fr
} 
microorganisms containing benefic and pathogenic microorganisms. These fermentations do not always guarantee product quality and safety and thus necessitates the use of pure starter cultures.

According to Holzapfel [7], the use of starter cultures containing microorganisms isolated from fermented products for fermentation would be an appropriate approach for the control and optimization of the fermentation process in order to alleviate the problems of variations in organoleptic quality and microbiological stability observed in African indigenous fermented foods. Previous studies have shown that lactic acid bacteria (LAB) are involved in the traditional Ivoirian sorghum-based beverages process, mainly during the spontaneous lactic fermentation [3]. The objective of the present study was to assess the selected LAB isolated from fermented sorghum-based beverages in Côte d'Ivoire for their performance as single strain starter cultures for production of sweet wort and tchapalo. We also determined whether the beverages obtained from the different starters inhibit some foodborne pathogens.

\section{Material and methods}

\subsection{Samples collection}

Red sorghum grains and samples of sour wort, sweet wort and tchapalo of three processes produced by a traditional brewer at Abobo Pk18 (Abidjan, Southern Côte d'Ivoire) using the red sorghum were collected. These samples were used as controls for samples that were prepared in the laboratory. They were collected in sterile bottles, labelled, and then transported to the laboratory in an icebox containing a freeze pack.

\subsection{Strains and growth conditions}

Twenty-three LAB (thirteen Lactobacillus fermentum, six Pediococcus acidilactici, three Pediococcus pentosaceus and one Lactobacillus plantarum) isolated from tchapalo process in previous study [8] were used to evaluate as single starter cultures for the different control fermentations. These strains were selected because they inhibited some foodborne pathogens by organic acids production. LAB strains were grown on MRS agar at $30{ }^{\circ} \mathrm{C}$ for $48 \mathrm{~h}$. An isolated colony was picked up and sub-cultured in MRS broth at $30^{\circ} \mathrm{C}$ for overnight. After growth, each LAB culture was centrifuged at 4000 $\times \mathrm{g}$ for $10 \mathrm{~min}$ and the pellet was collected for wort inoculation. Staphylococcus aureus, Escherichia coli and Salmonella typhi were used as foodborne pathogens. They were sub-cultured at $37^{\circ} \mathrm{C}$ in nutrient broth, after growing on nutriment agar. All these strains were obtained into the Laboratory of Food Biotechnology and Microbiology, faculty of food sciences and technologies, Nangui Abrogoua University, Côte d'Ivoire.

\subsection{Laboratory preparation of beverages}

\subsubsection{Preparation of wort}

Beverages were prepared according to brewers tchapalo process described by Aka et al. [1] using pure single starter cultures (Fig. 1). Red sorghum (Sorghum bicolor (L) Moench) grains (5 kg) collected from traditional brewer were sorted manually to remove debris. Then, the grains were steeped in water $(20 \mathrm{~L})$ at $37^{\circ} \mathrm{C}$ for $10 \mathrm{~h}$. After steeping, they were drained and were germinated at $37^{\circ} \mathrm{C}$ for 3 days before drying at ambient temperature for $24 \mathrm{~h}$. The dried malt obtained was milled to give malted sorghum flour. Then, $3.4 \mathrm{~kg}$ of malted sorghum flour were mixed with $20 \mathrm{~L}$ water containing $1 \%$ of grinding the bark of Anogeissus leocarpus and then left in decantation during $45 \mathrm{~min}$. Subsequently, $10 \mathrm{~L}$ of the supernatant were removed while the sediment was boiled at $100^{\circ} \mathrm{C}$ for $1 \mathrm{~h} 30 \mathrm{~min}$ to gelatinize malt starch. Then boiled sediment was mixed with the supernatant to give the wort. Finally, this wort was distributed in flasks ( $500 \mathrm{~mL}$ per flask) and was pasteurized at $63^{\circ} \mathrm{C}$ for $30 \mathrm{~min}$.

\subsubsection{Inoculation and fermentation assays}

The wort was inoculated with $1 \times 10^{6} \mathrm{CFU} / \mathrm{mL}$ of each single LAB starter culture and incubated at $30^{\circ} \mathrm{C}$ for $12 \mathrm{~h}$. For initial incubation and every $2 \mathrm{~h}, 15 \mathrm{~mL}$ was sampled under aseptic conditions for physico-chemical and microbiological analysis. After that, sour wort was obtained. Three trial fermentations were carried out.

\subsubsection{Sweet wort obtention and alcoholic fermentation}

The sour wort was boiled to obtain sweet wort whose total soluble solids (TSS) content was comprised between 11 and $14^{\circ}$ Brix and then cooled. Finally, 1\% commercial Saccharomyces cerevisiae starter was inoculated to sweet wort for alcoholic fermentation during $12 \mathrm{~h}$ according to N'Guessan et al. [9]. The product obtained after alcoholic fermentation was tchapalo. Three trial fermentations were carried out. 


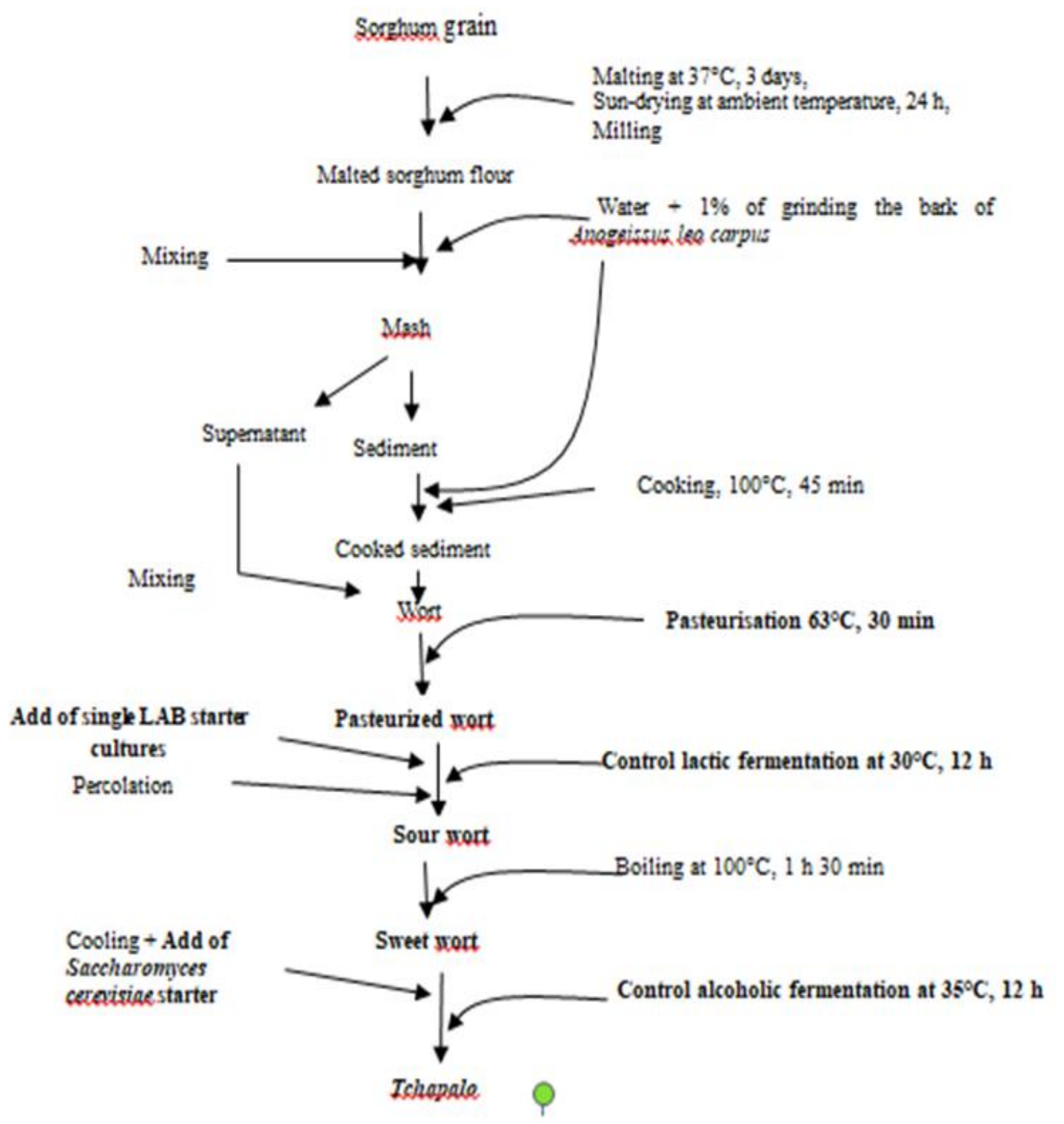

Figure 1 Diagram of tchapalo process in the laboratory using single starter cultures

\subsection{Physico-chemical analysis}

$\mathrm{pH}$ was measured using a digital pH-meter (P107 Consort). Acidification rate was calculated as $\Delta \mathrm{pH}$ according to Ayad et al. [10] ( $\Delta \mathrm{pH}=\mathrm{pH}$ at time - $\mathrm{pH}$ zero time). The Titratable Acidity (TA), expressed as a percentage of lactic acid, was determined by titration of $5 \mathrm{~mL}$ sample against $0.1 \mathrm{~N} \mathrm{NaOH}$ using phenolphthalein as indicator. Acid production rate was calculated as $\Delta \mathrm{AT}\left(\Delta \mathrm{AT}=\mathrm{AT}\right.$ at time $-\mathrm{AT}$ zero time). The Total Soluble Solids (TSS) content, expressed as ${ }^{\circ} \mathrm{Brix}$ value, was determined in each sample using a hand refractometer (ATAGO, N-20E, Japon). Two independent measurements were made for each sample. Organic acids were determined by High-Performance Liquid Chromatograph system (HPLC, LC-6A, Shimadzu corporation, Japan) according to Aka et al. [1]. Analyses were carried out with an ion- exclusion ORH-801 column $(300 \mathrm{~mm} \times 6.5 \mathrm{~mm}$ ) (Interchrom, France) preceded by a Universal Guard 
Aka et al. / GSC Biological and Pharmaceutical Sciences, 2020, 06(02), 182-195

Cartritge-Holder column. The HPLC was equipped of a Shimadzu LC-6A pump. Column effluents were monitored by an UV detector (SPD-6A, Shimadzu Corporation, Japan) set at $210 \mathrm{~nm}$. The mobile phase $(0.004 \mathrm{~N} \mathrm{H} 2 \mathrm{SO} 4)$ used at a flow rate of $0.8 \mathrm{~mL} / \mathrm{min}$ was filtered through a $0.45 \mu \mathrm{m}$ Millipore membrane filter (Sartorius AG, Goëttingen, Germany). Each sample was injected in duplicate. Organic acids were identified by comparing their retention times with those of standards.

\subsection{Microbiological analysis}

For enumeration of LAB, $10 \mathrm{~mL}$ of sample was homogenized in $90 \mathrm{~mL}$ sterile peptone water (pH 7.0) to obtain a 1:10 dilution. Further 10 -fold dilutions were prepared from this and $1 \mathrm{~mL}$ of an appropriate dilution was spread onto MRS agar. Plates were incubated at $30^{\circ} \mathrm{C}$ for $48 \mathrm{~h}$ and colony forming units (CFU/mL) estimated. The population growth dynamics $(\Delta$ Growth) of the LAB was calculated as $\Delta$ Growth $(\Delta$ Growth $=$ Growth at time - Growth zero time). Antibacterial activity was assayed using an agar diffusion method described by Arici et al. [11]. Ten (10) mL of sour wort, sweet wort and tchapalo resulting from inoculation of each LAB strain were centrifuged $(4000 \times \mathrm{g}$, TGL-16 M) at $4{ }^{\circ} \mathrm{C}$ for $10 \mathrm{~min}$. The supernatants were filtered through a $0.20 \mu \mathrm{m}$ pore size filter (Corning syringe filters, Sigma-Aldrich, Germany). An overnight culture of the target strain was diluted in sterile Mueller-Hinton Medium and $200 \mu \mathrm{L}$ of approximately $1 \times 10^{6} \mathrm{CFU} / \mathrm{mL}$ were spread on solid Mueller-Hinton Medium. Filtered samples $(100 \mu \mathrm{L})$ were spotted in wells ( $5 \mathrm{~mm}$ in diameter) on the agar plate. The plates were placed at $4{ }^{\circ} \mathrm{C}$ for $1 \mathrm{~h}$ and then incubated at $37^{\circ} \mathrm{C}$ for 24 $h$. The appearance of the clear zone around the wells of the growth of target strain was used to indicate inhibitory activity. Therefore, the diameters $(\mathrm{mm})$ of these zones were measured and recorded. Antibacterial tests were carried out in twice.

\subsection{Statistical analysis}

Results were statistically evaluated by one way analysis of variance (ANOVA) and Duncan's multiple range test with the software Statistica version 7.1. Differences were considered significant at $\mathrm{p}<0.05$ level.

\section{Results}

\subsection{Selection of starter cultures}

\subsubsection{Changes in $\mathrm{pH}$ and titratable acidity during sorghum wort fermentations using single starter cultures as inoculum}

Changes in $\mathrm{pH}$ and titratable acidity during sorghum wort fermentations using single starter cultures as inoculum were shown in Fig. 2 and Fig. 3 respectively. The pH of sorghum wort dropped whereas acidity increased. However, the acid production varied within strains of the same species and between species also. The $\Delta \mathrm{pH}$ of wort from strains varied significantly $(\mathrm{p}<0.05)$ from 0 unit to 2.15 units within $12 \mathrm{~h}$ of fermentation. Within $6 \mathrm{~h}$ of fermentation, out of twentythree bacteria, only six (26.08\%) of strains namely L. fermentum strains $S_{6}, S_{42}$ and $S_{45}$, P. acidilactici strains $S_{7}$ and $S_{52}$ and $P$. pentosaceus strain $\mathrm{S}_{5}$ accelerated fermentation by dropping of $\Delta \mathrm{pH}$ to $\geq 1.5$ units and increasing of $\Delta \mathrm{AT}$ to $\geq 0.15 \%$. After $8 \mathrm{~h}$ of fermentation, L. fermentum strains $\mathrm{S}_{6}, \mathrm{~S}_{8}, \mathrm{~S}_{9}, \mathrm{~S}_{11}, \mathrm{~S}_{13}, \mathrm{~S}_{41}, \mathrm{~S}_{42}$ and $\mathrm{S}_{45}$ dropped the $\mathrm{pH}$ to $\geq 1.7$ units while increasing the $\Delta \mathrm{AT}$ to $\geq 0.17 \%$. In the same time, P. acidilactici strains, P. pentosaceus strain and L. plantarum accelerated less fermentation of the sorghum wort than L. fermentum strains. A decrease of $\Delta \mathrm{pH}$ to $\leq 1.7$ units was observed except $P$. acidilactici strain S7 and P. pentosaceus strain S5 which were dropped pH to 1.74 and 1.96 units respectively. In short, ten strains out of twenty-three (43.47\%) quickly dropped the $\mathrm{pH}$ within $8 \mathrm{~h}$ of fermentation. After $12 \mathrm{~h}$ of fermentation, only $L$. fermentum strains $\mathrm{S}_{6}, \mathrm{~S}_{42}$ and $\mathrm{S}_{45}$ attained a $\Delta \mathrm{pH}$ to $\geq 2.1$ units and the increasing of $\Delta \mathrm{AT}$ to $\geq 0.3 \%$. However, $P$. acidilactici strain $\mathrm{S}_{5}$ decreased $\Delta \mathrm{pH}$ to 2.03 units and increased $\Delta \mathrm{AT}$ to $0.33 \%$. Pediococcus acidilactici strain $\mathrm{S}_{7}$ increased $\Delta$ AT to $0.35 \%$; while, the decrease of $\Delta \mathrm{pH}$ of $P$. pentosaceus strains $S_{5}$ and $S_{47}$ were to 2.11 and 1.99 units respectively with an increase of $\Delta \mathrm{TA}$ to 0.39 and $0.26 \%$ respectively. Furthermore, L. plantarum attained a $\Delta \mathrm{pH}$ to 1.9 units and $\Delta \mathrm{AT}$ to $0.24 \%$. 

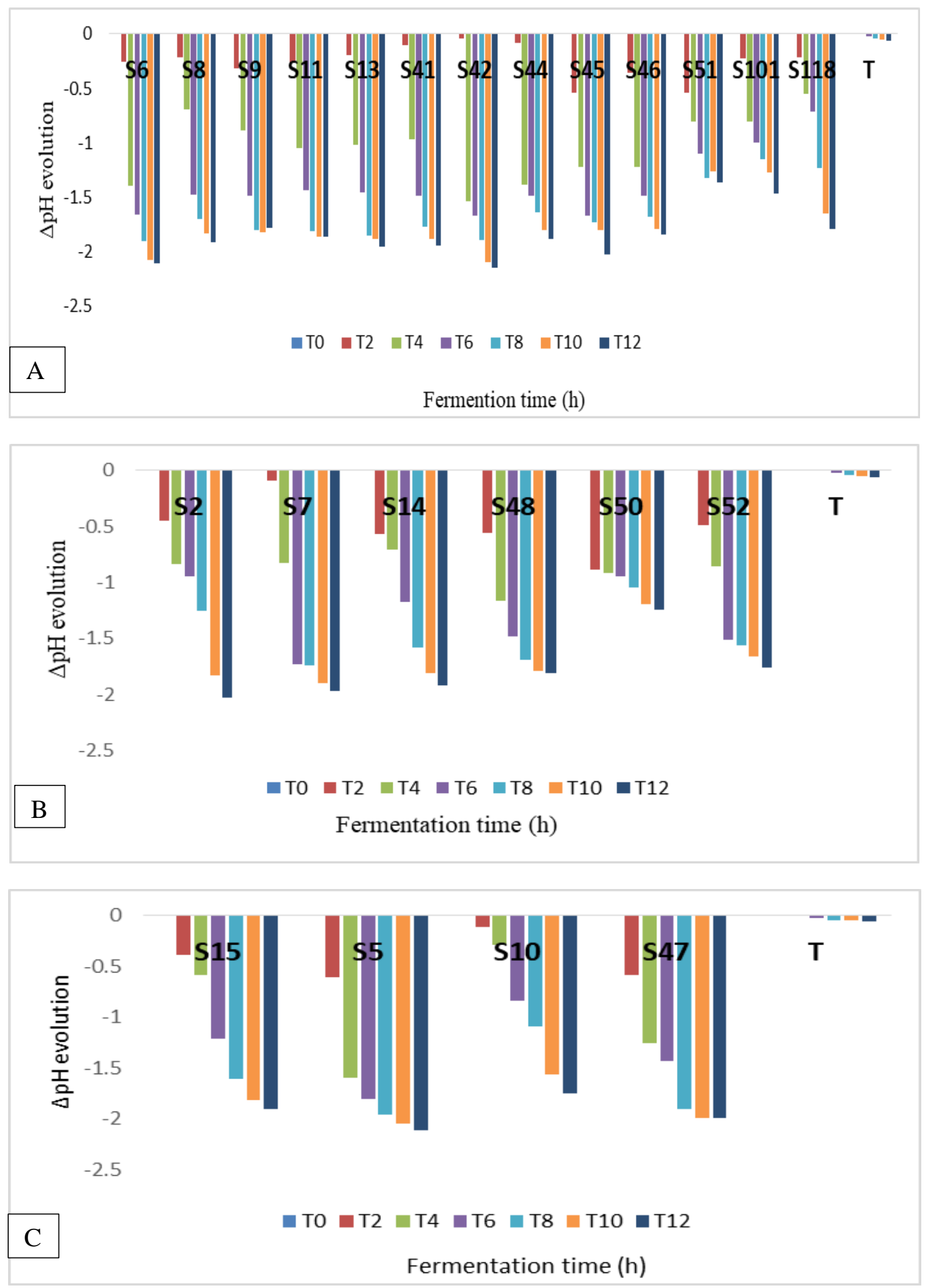

Figure 2 Changes in $\mathrm{pH}$ during sorghum wort fermentations using single starter cultures as inoculum. $\mathrm{A}=$ Lactobacillus fermentum strains; B = Pediococcus acidilactici strains; C = Pediococcus pentosaceus and Lactobacillus plantarum strains. 

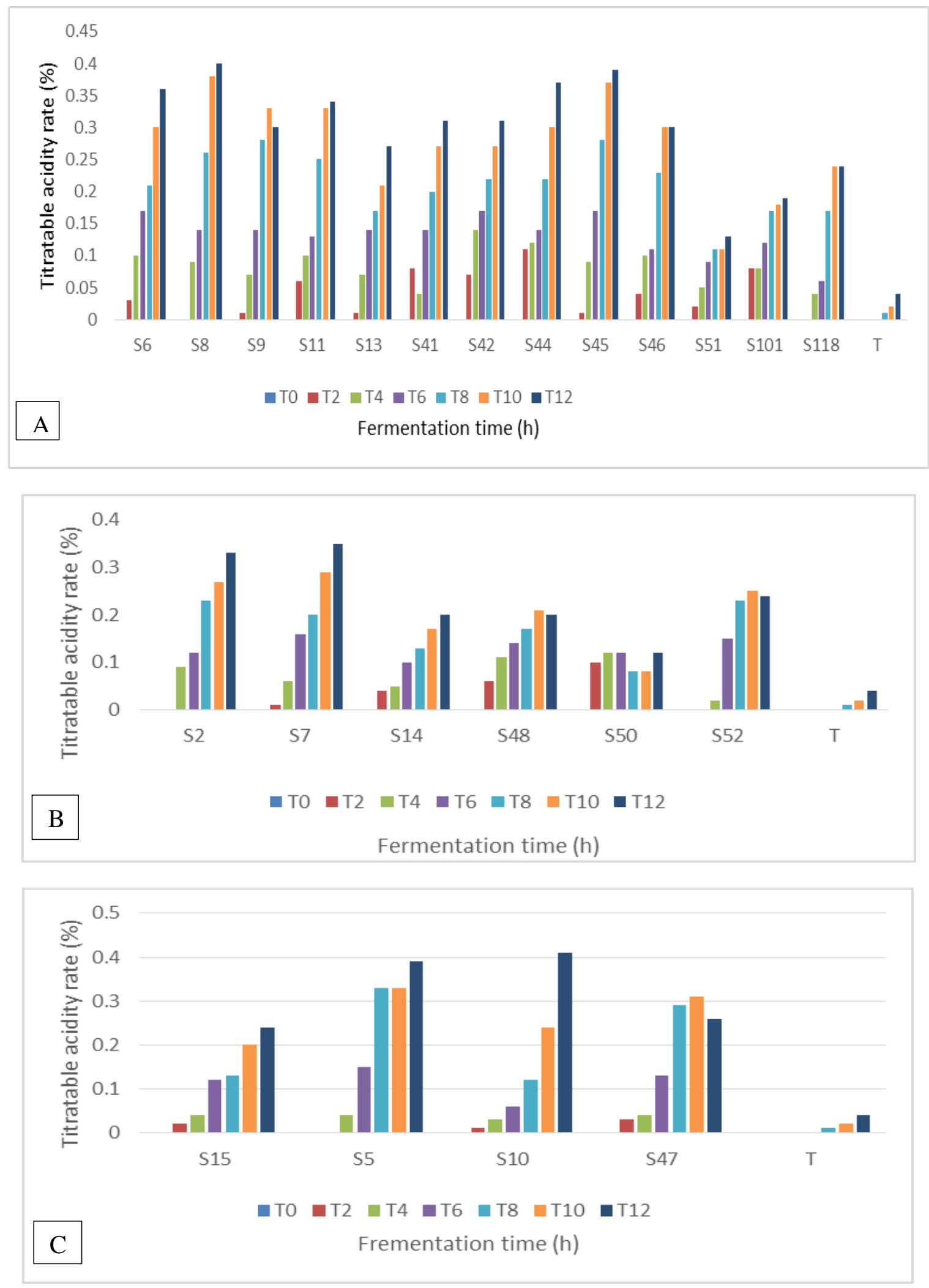

Figure 3 Changes in titratable acidity during sorghum wort fermentations using single starter cultures as inoculum. A = Lactobacillus fermentum strains; $\mathrm{B}=$ Pediococcus acidilactici strains; $\mathrm{C}=$ Pediococcus pentosaceus and Lactobacillus plantarum strains. 


\subsubsection{Growth dynamic of LAB species during fermentation}

Population growth dynamics of the LAB used as single starter cultures in the sorghum wort fermentations were monitored from $0 \mathrm{~h}$ to $12 \mathrm{~h}$ (Fig. 3). Results indicated that, generally, a lag phase was observed until to $2 \mathrm{~h}$ or $4 \mathrm{~h}$ according to LAB followed by an exponential growth. Then, came the stationary phase which ends with the decrease phase. Most of LAB achieved their exponential growth between $8 \mathrm{~h}$ and $10 \mathrm{~h}$ increasing their growth rate from 2.14$3.65 \log \mathrm{CFU} / \mathrm{mL}$ to 2.9-3.99 $\log \mathrm{CFU} / \mathrm{mL}$. Thereby, during exponential phase, the growth dynamic of L. fermentum group 1 increased from $0.05-0.18 \log \mathrm{CFU} / \mathrm{mL}$ to 2.21-3.07 log CFU/mL during $2 \mathrm{~h}$ to $8 \mathrm{~h}$ (Fig. 3A1). However, $L$. fermentum strain $\mathrm{S}_{6}$ carried out his growth rate from $0.18 \log \mathrm{CFU} / \mathrm{mL}$ to $2.67 \log \mathrm{CFU} / \mathrm{mL}$ during $2 \mathrm{~h}$ to $6 \mathrm{~h}$. During $8 \mathrm{~h}$ to $10 \mathrm{~h}$, the growth rate of $L$. fermentum group 1 increased slightly from $2.14-3.07 \log \mathrm{CFU} / \mathrm{mL}$ to $2.14-3.42 \log \mathrm{CFU} / \mathrm{mL}$; but L. fermentum strain $\mathrm{S}_{46}$ remained constant from $8 \mathrm{~h}$ to $12 \mathrm{~h}$ of fermentation with a growth rate of $2.14 \log \mathrm{CFU} / \mathrm{mL}$. A decrease of the growth rate was observed from 2.14-3.42 $\log \mathrm{CFU} / \mathrm{mL}$ to 1.78-2.55 $\log \mathrm{CFU} / \mathrm{mL}$ between $10 \mathrm{~h}$ to 12 $\mathrm{h}$ of fermentation except $L$. fermentum strains $S_{118}$ and $S_{41}$ which the growth rate increased slightly until to 3.1 and 3.59 $\log \mathrm{CFU} / \mathrm{mL}$ respectively. On the other hand, $2 \mathrm{~h}$ to $8 \mathrm{~h}$ growth rate of $L$. fermentum group 2 were lower than those of $L$. fermentum group 1 (Fig. 3A2). Until $12 \mathrm{~h}$ of fermentation, the stationary phase was not observed. At the level of sorghum wort that was inoculated with P. acidilactici strains, the exponential phase was taken place from $2 \mathrm{~h}$ to $8 \mathrm{~h}$ (Fig. 3B). During this phase, the growth rate went from $0.03-0.19 \log \mathrm{CFU} / \mathrm{mL}$ to $1.85-3.65 \log \mathrm{CFU} / \mathrm{mL}$ with the largest values observed in fermented wort from P. acidilactici strains $\mathrm{S}_{52}$ and $\mathrm{S}_{14}$ (3.39 and $3.65 \log$ CFU/mL respectively). Moreover, L. plantarum alone had a growth dynamic higher than all species which achieved during $6 \mathrm{~h}$ time of fermentation with a value of $3.88 \log \mathrm{CFU} / \mathrm{mL}$ (Fig. 3C). On the other hand, the highest growth rate for P. pentosaceus strain $\mathrm{S}_{5}$ was observed at $8 \mathrm{~h}$ of fermentation (3.17 $\log \mathrm{CFU} / \mathrm{mL}$, Fig. 3C).
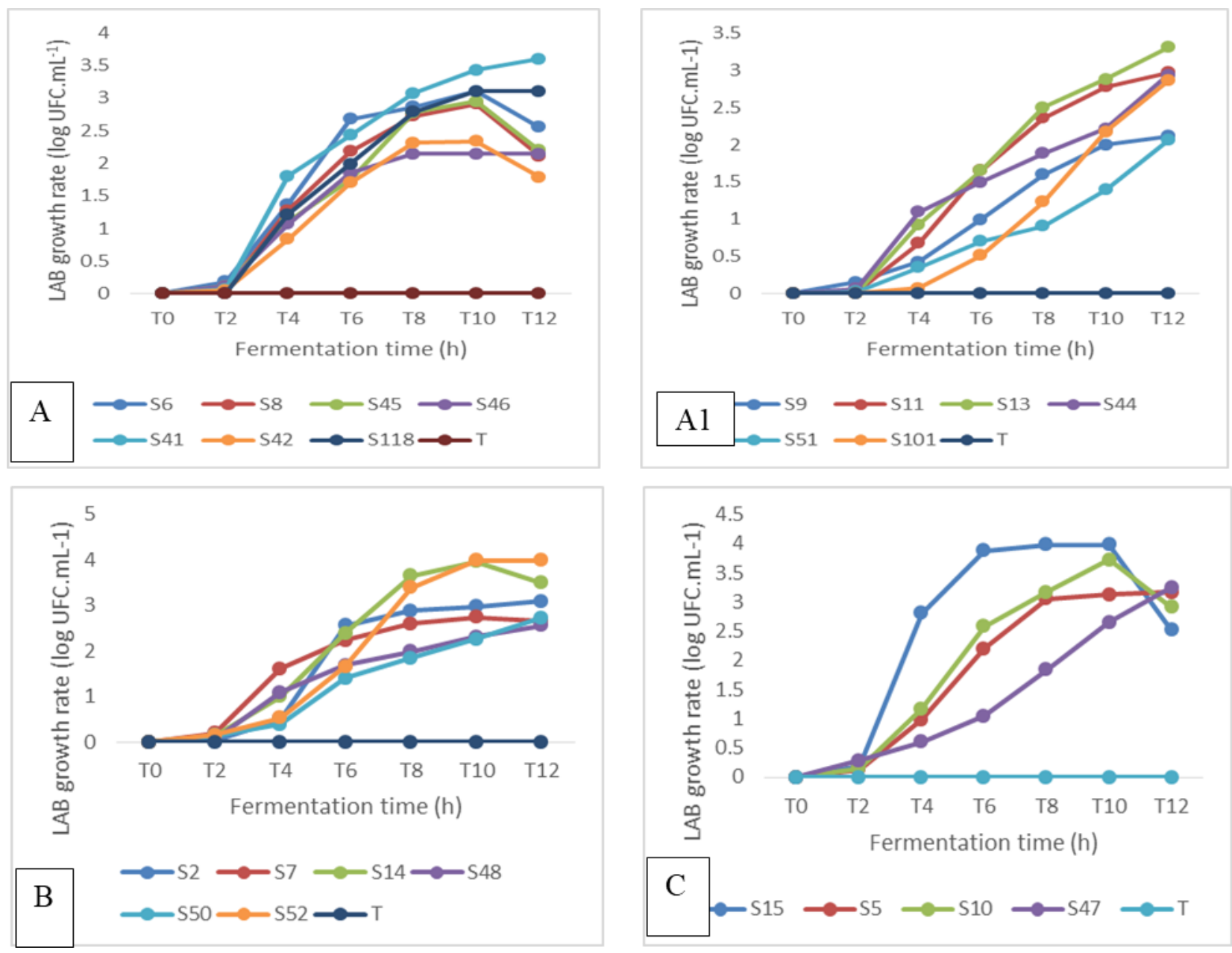

Figure 4 Growth rate of LAB species during sorghum wort fermentations using single starter cultures. A1 = Lactobacillus fermentum strains group 1; A2 = Lactobacillus fermentum strains group 2; B = Pediococcus acidilactici strains; $\mathrm{C}=$ Pediococcus pentosaceus and Lactobacillus plantarum strains. 
Aka et al. / GSC Biological and Pharmaceutical Sciences, 2020, 06(02), 182-195

\subsection{Characteristics of beverages from controlled fermentations}

\subsubsection{Biochemical characteristics}

The biochemical characteristics of beverages obtained by sorghum wort fermentations using L. fermentum strains $\mathrm{S}_{6}$, $S_{42}$ and $S_{45}$, P. acidilactici strains $S_{7}, S_{52}$ and $P$. pentosaceus strain $S_{5}$ as single starter cultures were shown in Tables 1,2 and 3. All $\mathrm{pH}$ of sour wort from fermentations with L. fermentum strains $\mathrm{S}_{6}, \mathrm{~S}_{42}$ and $\mathrm{S}_{45}$, P. acidilactici strains $\mathrm{S}_{7}$, $\mathrm{S}_{52}$ and $P$. pentosaceus strain $\mathrm{S}_{5}$ used as inoculum were lower with values between 3.6 and 4.0; while the $\mathrm{pH}$ of sour wort from brewer and spontaneous fermentation carried out in the laboratory used as controls were the same (pH $3.7 \pm 0.6$ and $3.7 \pm 0.8$ respectively). However, there was not significant difference $(\mathrm{P}>0.05)$. On the other hand, the sour wort from $L$. fermentum strains $S_{6}$ and $S_{45}$ had the highest titratable acidity $(0.4 \pm 0.1 \%$, Table 1$)$. The sweet wort from sour wort fermented with single LAB strains were also acid (pH: $3.3 \pm 0.3-3.9 \pm 0.1$ and titratable acidity: $0.3 \pm 0.1 \%$, Table 2 ). The titratable acidity of sweet wort from brewer and laboratory were comparative to those of starters; they were not significantly different $(p>0.05)$. Only tchapalo from spontaneous fermented wort carried out in the laboratory had the highest $\mathrm{pH}(4.5 \pm 0.5)$. This value was significantly different $(\mathrm{p}<0.05)$ to others. The lowest $\mathrm{pH}$ observed was those of the tchapalo obtained by brewer spontaneous fermented wort $(\mathrm{pH} 3.7 \pm 0.4)$. But this value was comparative to those of starters (Table 3).

The content of soluble solids of the sour wort from sorghum wort fermentations using single starter cultures varied between $5.0 \pm 0.0^{\circ} \mathrm{Brix}$ and $5.5 \pm 0.7^{\circ} \mathrm{Brix}$, but there was not significant difference $(\mathrm{P}>0.05)$ between these values (Table 1). Those of brewer spontaneous fermented sour wort was $6.0 \pm 1.4^{\circ}$ Brix. However, the increase of content of soluble solids was observed in the sweet wort obtained according to starter cultures. The highest content of soluble solids was noted in sweet wort fermented with $P$. acidilactici strains $\mathrm{S}_{7}\left(13.0 \pm 1.4^{\circ} \mathrm{Brix}\right.$, Table 2$)$; while the lowest content of soluble solids was observed in sweet wort fermented with P. acidilactici strain $S_{52}\left(10.5 \pm 0.7^{\circ} \mathrm{Brix}\right)$. All the content of soluble solids of tchapalo were lower than those of sweet wort. On the other hand, the content of soluble solids of tchapalo from L. fermentum $\mathrm{S}_{6}\left(4.5 \pm 0.7^{\circ} \mathrm{Brix}\right)$, P. acidilactici $\mathrm{S}_{7}\left(5.0 \pm 0,0{ }^{\circ} \mathrm{Brix}\right)$, L. fermentum $\mathrm{S}_{45}\left(4.3 \pm 0.4^{\circ}\right.$ Brix $)$ and P. acidilactici $\mathrm{S}_{52}$ $\left(4.3 \pm 1.8^{\circ} \mathrm{Brix}\right)$ were significantly comparable with tchapalo from brewer spontaneous fermented $\left(5.5 \pm 0.7^{\circ} \mathrm{Brix}\right)$.

Tartaric and lactic acids were detected in all the fermented sour wort with single starter cultures with a predominance of lactic acid, but their contents varied according to starter cultures (Table 1). Thereby, the highest contents of tartaric acid were found in sour wort from P. pentosaceus $\mathrm{S}_{5}(4.01 \pm 0.52 \mathrm{~g} / \mathrm{L})$, P. acidilactici $\mathrm{S}_{7}(3.81 \pm 0.03 \mathrm{~g} / \mathrm{L})$ and L. fermentum $\mathrm{S}_{42}(3.68 \pm 0.32 \mathrm{~g} / \mathrm{L})$. These values were significantly different $(\mathrm{P}<0.05)$ to the brewer spontaneous fermented sour wort $(0.67 \pm 0.24 \mathrm{~g} / \mathrm{L})$. Otherwise, sour wort produced with L. fermentum $\mathrm{S}_{6}(9.74 \pm 0.98 \mathrm{~g} / \mathrm{L})$, L. fermentum $\mathrm{S}_{42}(9.46 \pm 0.23 \mathrm{~g} / \mathrm{L})$ and P. pentosaceus $S_{5}(8.12 \pm 0.07 \mathrm{~g} / \mathrm{L})$ contained higher lactic acid than those of other sour wort but there was not significantly different $(\mathrm{P}>0.05)$. Acetic acid was only detected in fermented sour wort with $L$. fermentum strains $(0.06 \pm 0.01-0.07 \pm 0.01 \mathrm{mg} / \mathrm{L})$ and sour wort from spontaneous fermentation carried out in the laboratory $(0.17 \pm 0.03$ $\mathrm{mg} / \mathrm{L}$ ). On the other hand, fumaric acid was not detected in sour wort produced with $P$. acidilactici strains. In all sweet wort, contents of organic acids were strongly high than in sour wort (Table 2). Lactic acid was higher than other organic acids. The lactic acid content of sweet wort from P. acidilactici strain $\mathrm{S}_{7}(51.73 \pm 0.02 \mathrm{~g} / \mathrm{L})$ was highest and significantly different $(\mathrm{P}<0.05)$ of those of brewer spontaneous fermented sweet wort $(19.78 \pm 0.93 \mathrm{~g} / \mathrm{L})$ and the all others sweet wort. In the tchapalo, no acetic acid was detected (Table 3). On the other hand, there were tartaric, lactic and fumaric acids whose content is lower than those of sweet wort from which they were derived. Thus, the lowest lactic acid content was observed in the tchapalo from L. fermentum strains $S_{45}(9.77 \pm 0.23 \mathrm{~g} / \mathrm{L})$. However, this content did not vary significantly $(\mathrm{P}>0.05)$ in tchapalo obtained by spontaneous fermentation from the brewer $(11.61 \pm 0.28 \mathrm{~g} / \mathrm{L})$. 
Table 1 Biochemical characteristics of sour wort from sorghum wort fermentations using single starter cultures

\begin{tabular}{|c|c|c|c|c|c|c|c|c|c|}
\hline \multirow[t]{3}{*}{ Characteristics } & \multicolumn{9}{|l|}{ Sour wort } \\
\hline & \multicolumn{6}{|c|}{ Single starter cultures } & \multicolumn{3}{|l|}{ Controls } \\
\hline & $\mathrm{S}_{5}$ & $\mathrm{~S}_{6}$ & $\mathrm{~S}_{7}$ & $\mathrm{~S}_{42}$ & $\mathrm{~S}_{45}$ & $\mathrm{~S}_{52}$ & $\mathrm{~T}_{\mathrm{F}}$ & $\mathrm{T}_{\mathrm{L}}$ & TB \\
\hline $\mathrm{pH}$ & $3.6 \pm 0.3^{a}$ & $3.9 \pm 0.3^{\mathrm{a}}$ & $3.5 \pm 0.1^{\mathrm{a}}$ & $3.8 \pm 0.4^{\mathrm{a}}$ & $4.0 \pm 0.8^{\mathrm{a}}$ & $3.7 \pm 0.1^{\mathrm{a}}$ & $3.7 \pm 0.6^{\mathrm{a}}$ & $3.7 \pm 0.8^{\mathrm{a}}$ & $6.6 \pm 0.0^{c}$ \\
\hline AT (\% lactic acid) & $0.3 \pm 0.1^{\mathrm{a}}$ & $0.4 \pm 0.1^{\mathrm{a}}$ & $0.2 \pm 0.0^{\mathrm{a}}$ & $0.3 \pm 0.1^{\mathrm{a}}$ & $0.4 \pm 0.1^{\mathrm{a}}$ & $0.3 \pm 0.1^{\mathrm{a}}$ & $0.2 \pm 0.1^{\mathrm{a}}$ & $0.2 \pm 0.1^{\mathrm{a}}$ & $0.1 \pm 0.0$ \\
\hline $\operatorname{TSS}\left({ }^{\circ} \mathrm{Brix}\right)$ & $5.0 \pm 0.0^{\mathrm{a}}$ & $5.0 \pm 0.0^{\mathrm{a}}$ & $5.5 \pm 0.7^{\mathrm{a}}$ & $5.0 \pm 0.0^{\mathrm{a}}$ & $5.0 \pm 0.0^{\mathrm{a}}$ & $5.5 \pm 0.7^{\mathrm{a}}$ & $6.0 \pm 1.4^{\mathrm{a}}$ & $5.0 \pm 0.0^{\mathrm{a}}$ & $5.0 \pm 0.0^{\mathrm{a}}$ \\
\hline Tartaric acid (g/L) & $4.01 \pm 0.52^{\mathrm{c}}$ & $1.44 \pm 0.06^{b}$ & $3.81 \pm 0.03^{c}$ & $3.68 \pm 0.32^{\mathrm{c}}$ & $1.36 \pm 0.4^{b}$ & $2.36 \pm 0.23^{b}$ & $0.67 \pm 0.24^{\mathrm{a}}$ & $2.29 \pm 0.17^{b}$ & $1.92 \pm 0.44^{b}$ \\
\hline Acetic acid (mg/L) & 0 & $0.06 \pm 0.01^{\mathrm{a}}$ & 0 & $0.07 \pm 0.01^{\mathrm{a}}$ & $0.06 \pm 0.01^{\mathrm{a}}$ & 0 & 0 & $0.17 \pm 0.03^{\mathrm{a}}$ & 0 \\
\hline Lactic acid (g/L) & $8.12 \pm 0.07^{b}$ & $9.74 \pm 0.98^{b}$ & $7.57 \pm 0.99 b$ & $9.46 \pm 0.23^{b}$ & $7.39 \pm 0.74^{b}$ & $7.28 \pm 0.24^{b}$ & $7.85 \pm 0.5^{b}$ & $7.30 \pm 0.16^{b}$ & $0.86 \pm 0.01^{b}$ \\
\hline Fumaric acid (mg/L) & $0.58 \pm 0.32^{\mathrm{a}}$ & $4.99 \pm 0.04^{c}$ & 0 & $3.7 \pm 0.02^{b}$ & $0.43 \pm 0.03^{\mathrm{a}}$ & 0 & $0.37 \pm 0.05^{\mathrm{a}}$ & $4.73 \pm 0.34^{c}$ & $4.4 \pm 1.1^{b c}$ \\
\hline
\end{tabular}

Table 2 Biochemical characteristics of sweet wort from sorghum wort fermentations using single starter cultures

\begin{tabular}{|c|c|c|c|c|c|c|c|c|c|}
\hline \multirow[t]{3}{*}{ Characteristics } & \multicolumn{9}{|l|}{ Sweet wort } \\
\hline & \multicolumn{6}{|c|}{ Single starter cultures } & \multicolumn{3}{|l|}{ Controls } \\
\hline & $\mathrm{S}_{5}$ & $\mathrm{~S}_{6}$ & $\mathrm{~S}_{7}$ & $\mathrm{~S}_{42}$ & $\mathrm{~S}_{45}$ & $\mathrm{~S}_{52}$ & $\mathrm{~T}_{\mathrm{F}}$ & $\mathrm{T}_{\mathrm{L}}$ & TB \\
\hline $\mathrm{pH}$ & $3.3 \pm 0.3^{\mathrm{a}}$ & $3.9 \pm 0.3^{a}$ & $3.8 \pm 0.2^{\mathrm{a}}$ & $3.8 \pm 0.1^{\mathrm{a}}$ & $3.9 \pm 0.1^{\mathrm{a}}$ & $3.4 \pm 0.4^{\mathrm{a}}$ & $3.5 \pm 0.1^{\mathrm{a}}$ & $3.9 \pm 1.2^{\mathrm{a}}$ & $6.6 \pm 0.0^{c}$ \\
\hline AT (\% lactic acid) & $0.3 \pm 0.1^{\mathrm{a}}$ & $0.3 \pm 0.1^{\mathrm{a}}$ & $0.3 \pm 0.1^{\mathrm{a}}$ & $0.3 \pm 0.2^{\mathrm{a}}$ & $0.3 \pm 0.1^{\mathrm{a}}$ & $0.3 \pm 0.1^{\mathrm{a}}$ & $0.3 \pm 0.1^{\mathrm{a}}$ & $0.3 \pm 0.1^{\mathrm{a}}$ & $0.1 \pm 0.0$ \\
\hline TSS $\left({ }^{\circ}\right.$ Brix $)$ & $11.5 \pm 2.1^{\mathrm{b}}$ & $12.3 \pm 1.8^{b}$ & $13.0 \pm 1.4^{b}$ & $11.1 \pm 1.3^{b}$ & $11.8 \pm 3.2^{\mathrm{b}}$ & $10.5 \pm 0.7^{b}$ & $12.2 \pm 1.7^{b}$ & $14.0 \pm 2.1^{\mathrm{b}}$ & $5.0 \pm 0.0^{\mathrm{a}}$ \\
\hline Tartaric acid (g/L) & $6.88 \pm 0.22^{c}$ & $5.58 \pm 0.47^{c}$ & $12.13 \pm 2.12^{\mathrm{d}}$ & $12.07 \pm 0.44^{d}$ & $6.97 \pm 1.1^{c}$ & $6.28 \pm 1.32^{\mathrm{c}}$ & $2.38 \pm 0.37^{b}$ & $6.97 \pm 1.64^{c}$ & $1.92 \pm 0.44^{\mathrm{a}}$ \\
\hline Acetic acid (mg/L) & 0 & $0.15 \pm 0.05^{\mathrm{a}}$ & 0 & $0.16 \pm 0.02^{\mathrm{a}}$ & $0.17 \pm 0.02^{\mathrm{a}}$ & 0 & 0 & $1.1 \pm 0.03^{\mathrm{b}}$ & 0 \\
\hline Lactic acid (g/L) & $35.93 \pm 0.23^{f}$ & $18.59 \pm 0.1^{\mathrm{c}}$ & $51.73 \pm 0.02^{\mathrm{g}}$ & $23.16 \pm 0.33^{d}$ & $9.79 \pm 0.03^{b}$ & $30.69 \pm 0.01^{\mathrm{e}}$ & $19.78 \pm 0.93^{d}$ & $9.69 \pm 0.01^{b}$ & $0.86 \pm 0.01^{\mathrm{a}}$ \\
\hline Fumaric acid (mg/L) & $6.42 \pm 0.18^{c}$ & $7.17 \pm 0.1^{\mathrm{d}}$ & $0.07 \pm 0.02^{\mathrm{a}}$ & $8.72 \pm 1.08^{e}$ & $4.73 \pm 0.2^{\mathrm{b}}$ & $0.77 \pm 0.11^{\mathrm{a}}$ & $4.94 \pm 0.32^{\mathrm{b}}$ & $6.48 \pm 0.4^{\mathrm{c}}$ & $4.4 \pm 1.1^{\mathrm{b}}$ \\
\hline
\end{tabular}


Aka et al. / GSC Biological and Pharmaceutical Sciences, 2020, 06(02), 182-195

Table 3 Biochemical characteristics of tchapalo from sorghum wort fermentations using single starter cultures

\begin{tabular}{|c|c|c|c|c|c|c|c|c|c|}
\hline \multirow[t]{3}{*}{ Characteristics } & \multicolumn{9}{|l|}{ Tchapalo } \\
\hline & \multicolumn{6}{|l|}{$\begin{array}{l}\text { Single } \\
\text { starter } \\
\text { cultures }\end{array}$} & \multicolumn{3}{|l|}{ Controls } \\
\hline & $\mathrm{S}_{5}$ & $\mathrm{~S}_{6}$ & $\mathrm{~S}_{7}$ & $\mathrm{~S}_{42}$ & $\mathrm{~S}_{45}$ & $\mathrm{~S}_{52}$ & $\mathrm{~T}_{\mathrm{F}}$ & $\mathrm{T}_{\mathrm{L}}$ & TB \\
\hline $\mathrm{pH}$ & $3.9 \pm 0.3^{\mathrm{ab}}$ & $4.0 \pm 0.1^{\mathrm{ab}}$ & $3.8 \pm 0.3^{\mathrm{ab}}$ & $3.9 \pm 0.1^{\mathrm{ab}}$ & $3.9 \pm 0.1^{\mathrm{ab}}$ & $3.8 \pm 0.0^{\mathrm{ab}}$ & $3.7 \pm 0.4^{\mathrm{a}}$ & $4.5 \pm 0.5^{b}$ & $6.6 \pm 0.0^{c}$ \\
\hline AT (\% lactic acid) & $0.4 \pm 0.1^{\mathrm{a}}$ & $0.4 \pm 0.1^{\mathrm{a}}$ & $0.4 \pm 0.1^{\mathrm{a}}$ & $0.4 \pm 0.0^{\mathrm{a}}$ & $0.4 \pm 0.0^{\mathrm{a}}$ & $0.4 \pm 0.1^{\mathrm{a}}$ & $0.4 \pm 0.1^{\mathrm{a}}$ & $0.3 \pm 0.1^{\mathrm{a}}$ & $0.1 \pm 0.0$ \\
\hline TSS ( ${ }^{\circ}$ Brix) & $3.3 \pm 0.4^{\mathrm{a}}$ & $4.5 \pm 0.7 \mathrm{ab}$ & $5.0 \pm 0.0^{\mathrm{ab}}$ & $3.5 \pm 0.7^{\mathrm{a}}$ & $4.3 \pm 0.4^{\mathrm{ab}}$ & $4.3 \pm 1.8^{\mathrm{ab}}$ & $5.5 \pm 0.7^{b}$ & $6.0 \pm 0.0^{b}$ & $5.0 \pm 0.0^{\mathrm{ab}}$ \\
\hline Tartaric acid (g/L) & $3.97 \pm 1.08^{b}$ & $4.91 \pm 0.8^{b}$ & $13.29 \pm 0.23^{\mathrm{d}}$ & $9.01 \pm 0.84^{c}$ & $3.76 \pm 0.41^{b}$ & $4.78 \pm 0.08^{b}$ & 0 & $3.56 \pm 0.49^{b}$ & $1.92 \pm 0.44^{\mathrm{a}}$ \\
\hline Acetic acid (mg/L) & 0 & 0 & 0 & 0 & 0 & 0 & 0 & 0,00 & 0 \\
\hline Lactic acid (g/L) & $16.94 \pm 0.07 \mathrm{de}$ & $14.27 \pm 0.14^{\mathrm{d}}$ & $17.24 \pm 1.22^{\mathrm{e}}$ & $11.83 \pm 3.32^{c}$ & $9.77 \pm 0.23^{b}$ & $13.79 \pm 0.96^{\mathrm{cd}}$ & $11.61 \pm 0.28 \mathrm{bc}$ & $9.67 \pm 0.25^{b}$ & $0.86 \pm 0.01^{\mathrm{a}}$ \\
\hline Fumaric acid (mg/L) & $11.97 \pm 0.67^{e}$ & 0 & 0 & $4.76 \pm 0.47^{b}$ & $6.29 \pm 1.02^{c}$ & $0.67 \pm 0.34^{\mathrm{a}}$ & $8.25 \pm 0.94^{d}$ & $6.29 \pm 1.2^{c}$ & $4.4 \pm 1.1^{b}$ \\
\hline
\end{tabular}

Values are expressed as means \pm standard deviation for three independent fermentations. Means values with same letter in a line for each parameter are not significantly different (P > 0.05). AT: titratable acidity, TSS: total soluble solids; $\mathrm{S}_{6}, \mathrm{~S}_{42}, \mathrm{~S}_{45}$ : L. fermentum strains, $\mathrm{S}_{7}, \mathrm{~S}_{52}$ : P. acidilactici strains, $\mathrm{S}_{5}$ : P. pentosaceus strain 


\subsubsection{Antibacterial properties}

Inhibition spectra of sour wort, sweet wort and tchapalo produced with single starter cultures are shown in Table 4. Sour wort did not display bactericidal activity against the indicator strains. On the other hand, all sweet wort and tchapalo produced with single starter cultures were able to inhibit the growth of E. coli, S. typhi and S. aureus. The inhibition diameters were ranged from $11 \pm 1$ to $23 \pm 6 \mathrm{~mm}$ according to sweet wort and indicator strains. The highest diameters were observed against $E$. coli $(19 \pm 1-23 \pm 6 \mathrm{~mm})$. All tchapalo exhibited also antibacterial activity against $S$. aureus $(11 \pm 1-15 \pm 1 \mathrm{~mm})$. However, only tchapalo from P. acidilactici $\mathrm{S}_{7}$, L. fermentum $\mathrm{S}_{45}$ and P. acidilactici $\mathrm{S}_{52}$ had antagonist activity against $E$. coli $(14 \pm 1-15 \pm 1 \mathrm{~mm})$. Salmonella typhi was the most sensitive indicator strain to tchapalo with single starter cultures.

Table 4 Antimicrobial activity of beverages from controlled fermentations against indicator strains

\begin{tabular}{lllllllllll}
\hline \multirow{2}{*}{ Beverages } & \multicolumn{2}{l}{ Indicator strains } & \multicolumn{3}{c}{ Single starter cultures } & \multicolumn{5}{c}{ Controls } \\
\cline { 2 - 11 } & & $\mathrm{S}_{5}$ & $\mathrm{~S}_{6}$ & $\mathrm{~S}_{7}$ & $\mathrm{~S}_{42}$ & $\mathrm{~S}_{45}$ & $\mathrm{~S}_{52}$ & $\mathrm{TF}$ & $\mathrm{TL}$ & $\mathrm{TB}$ \\
\hline \multirow{2}{*}{ Sour wort } & E. coli & 0 & 0 & 0 & 0 & 0 & 0 & 0 & 0 & 0 \\
& S. typhi & 0 & 0 & 0 & 0 & 0 & 0 & 0 & 0 & 0 \\
& S. aureus & 0 & 0 & 0 & 0 & 0 & 0 & 0 & 0 & 0 \\
\multirow{5}{*}{ Sweet wort } & E. coli & $23 \pm 6$ & $22 \pm 6$ & $21 \pm 4$ & $23 \pm 6$ & $19 \pm 1$ & $23 \pm 6$ & $19 \pm 8$ & $21 \pm 4$ & 0 \\
& S. typhi & $15 \pm 1$ & $15 \pm 1$ & $17 \pm 2$ & $18 \pm 4$ & $19 \pm 5$ & $16 \pm 1$ & $15 \pm 2$ & $15 \pm 7$ & 0 \\
& S. aureus & $16 \pm 4$ & $12 \pm 0$ & $20 \pm 3$ & $17 \pm 1$ & $17 \pm 2$ & $18 \pm 4$ & $19 \pm 2$ & $11 \pm 1$ & 0 \\
& E. coli & 0 & 0 & $14 \pm 1$ & 0 & $15 \pm 1$ & $15 \pm 0$ & $16 \pm 1$ & 0 & 0 \\
& S. typhi & 0 & 0 & 0 & 0 & 0 & 0 & $16 \pm 1$ & 0 & 0 \\
& S. aureus & $13 \pm 1$ & $13 \pm 1$ & $15 \pm 1$ & $12 \pm 1$ & $11 \pm 1$ & $13 \pm 1$ & $12 \pm 3$ & $11 \pm 1$ & 0 \\
\hline
\end{tabular}

\section{Discussion}

The selection of LAB as starter cultures for cereal fermentation is a complex process, involving the evaluation of some desired metabolic traits and technological performances such as rapid acidification, rapid growth, production of antimicrobial compounds, reduction of hygienic risks $[7,12,13]$. When the lactic acid bacteria were used as single starter cultures in the sorghum wort for fermentations, $\mathrm{pH}$ of this dropped significantly at the end of fermentation whereas the titratable acidity increased. This can be explained by the fact that these bacteria used sugar, the main compound of sorghum wort, to produce organic acids which decreased the $\mathrm{pH}$ as described by many authors [13-16]. However, acid production varied within strains of the same species and between species also. Thereby, within $6 \mathrm{~h}$ of fermentation, out of twenty three bacteria, only six (26.08\%) namely L. fermentum strains $\mathrm{S}_{6}, \mathrm{~S}_{42}$ and $\mathrm{S}_{45}$, P. acidilactici strains $S_{7}$ and $S_{52}$ and P. pentosaceus strain $S_{5}$ accelerated fermentation by dropping of $\Delta \mathrm{pH}$ to $\geq 1.5 \mathrm{pH}$ units and increasing of $\Delta \mathrm{AT}$ to $\geq 0.15 \%$. These bacteria are distinguished from others by quickly acidification. These results were comparable to those of Sawadogo-Lingani et al. [17]. During their study on technological properties of Lactobacillus fermentum isolates involved in spontaneous fermentation of dolo and pito wort to select starter cultures, authors have shown that the faster acidifying group of isolates (which represent $43.48 \%$ ) had a acidification rate evaluated as $\Delta \mathrm{pH}$ of $1.14 \pm 0.15 \mathrm{pH}$ unit after $6 \mathrm{~h}$ of fermentation. Other authors mentioned the highest acidification power of LAB in many fermented products [18-20].

Acidification was correlated with growth rate of LAB. The same observations were made when Viera-Dalodé et al. [21] have used LAB individually or in combination with yeasts as inoculum enrichment for controlled fermentation of gowé. Most of LAB achieved their exponential phase between $8 \mathrm{~h}$ and $10 \mathrm{~h}$ increasing their growth dynamic from 2.14-3.65 $\log \mathrm{CFU} / \mathrm{mL}$ to 2.9-3.99 $\log \mathrm{CFU} / \mathrm{mL}$. On the other hand, after $6 \mathrm{~h}$ of fermentation, L. plantarum $\mathrm{S}_{15}$ achieved its exponential phase, but did not quickly acidify the sorghum wort unlike $L$ fermentum $\mathrm{S}_{6}$ which achieved its exponential phase at the same time and quickly acidified the sorghum wort. These results are contrary to those of Apaliya et al. [14], the microbial population in the fermentation of millet beverage with L. plantarum $\mathrm{S}_{2}$ was significantly higher than all the other treatments and his $\mathrm{pH}$ was the lowest also. 
All the beverages i. e. sour wort, sweet wort and tchapalo from single starters LAB had an acid pH like those of brewer obtained by spontaneous fermentation [1, 4, 5, 22]. This acidity was desirable and wished. Indeed, Aka et al. [1] mentioned that in the tchapalo process, acidity of sour wort was obligatory and important because it determined the further to process, organoleptic properties and the preserving of sweet wort and tchapalo. The content of soluble solids of the sweet wort were higher than those of sour wort because sour wort was cooked during 4 to 6 hours to sweet wort. This cooking leads to a concentration of soluble solids into the sweet wort [1]. Our finding was similar to those of Maoura et al. [23] which found that the soluble sugar had increased a lot after cooking initial wort to give cooked wort. All soluble solid contents of tchapalo were lower than those of sweet wort. This decrease was the result of the utilization of soluble solids as a carbon source by yeast to produce ethanol $[2,4,23,24]$. The content of soluble solids of tchapalo from L. fermentum $\mathrm{S}_{6}$, L. fermentum $\mathrm{S}_{45}$, P. acidilactici $\mathrm{S}_{7}$ and P. acidilactici $\mathrm{S}_{52}$ were significantly comparable with tchapalo from brewer spontaneous fermented. All the fermented sour worts with single starter cultures contained organic acids specifically lactic acid reducing the $\mathrm{pH}$ of the fermenting wort. These organic acids gave the souring taste to sour wort which is characteristic of this beverage [25]. The lactic acid content of sweet wort was highest to those of sour wort. This highest content would develop the desired flavor and reduce $\mathrm{pH}$ thus preventing growth of undesirable microorganisms and contributing to the development of the desired sensory qualities [26]. In the tchapalo, there was not acetic acid detected. Our results were in agreement with those of Dje et al. [24], which worked on biochemical changes during alcoholic fermentation in the production of tchapalo. They found that organic acid (oxalic, citric, tartaric, malic, lactic, fumaric and propionic acids) were found in the wort and in tchapalo and increased or decreased during fermentation differently from one site to another. But acetic acid was not always detected in both the wort and the beer.

The beverages such as sweet wort and tchapalo produced with single starter cultures had the ability to inhibit E. coli, $S$. typhi and S. aureus. Their inhibitory effects could be related to their organic acids content and composition $[1,8,26]$. Indeed, Byakika et al. [26] reported that organic acids inhibit pathogens by entering into cells in an undissociated form and dissociating within the cytoplasm. This lowers the intracellular $\mathrm{pH}$, and to maintain balance, cells use ATP to expel the excess hydrogen ions. This exhausts the cell of energy required for growth and other metabolic processes resulting in death. Thus, this beverage property improved his safety. Other researchers showed antimicrobial activities of traditional food and beverages against both Gram-negative and Gram-positive bacteria specifically food born bacteria $[27,28]$. Detha and Datta [28] indicated that Sopi and Moke, two traditional wines in Indonesia, have antimicrobial effects on E. coli and Salmonella sp., both Gram-negative bacteria.

\section{Conclusion}

The results obtained in this study showed that LAB, used as single starter cultures in the sorghum wort for fermentations, grew increasing organic acids and titratable acid and dropping $\mathrm{pH}$. But, L. fermentum strains $\mathrm{S}_{6}, \mathrm{~S}_{42}$ and $\mathrm{S}_{45}$, P. acidilactici strains $\mathrm{S}_{7}, \mathrm{~S}_{52}$ and $P$. pentosaceus strain $\mathrm{S}_{5}$ quickly acidified the sorghum wort. These bacteria have used to produce sweet wort and tchapalo similar to those of brewer obtained by spontaneous fermentation. These beverages were able to inhibit the growth of Escherichia coli, Salmonella typhimurium and Staphylococcus aureus. Further research will focus on organoleptic properties of trial fermentations with these LAB in co-cultures. Bacteria with good fermentation behaviour will be selected and used to produce a starter cultures for sweet wort and tchapalo commercial production and thereby to improve their safety and consumer acceptability of these products.

\section{Compliance with ethical standards}

\section{Acknowledgments}

This work was supported by the International Foundation for Science (IFS), Sweden [E/5169-2F]. The authors would gratefully acknowledge IFS, M. ZAHOUO Landry for his assistance in HLPC analysis, the tchapalo brewer for his collaboration and all the staff of Centre Suisse de Recherches Scientifiques en Côte d'Ivoire for english editing.

\section{Disclosure of conflict of interest}

The authors declare that there is no conflict of interests regarding the publication of this paper. 


\section{References}

[1] Aka S, N'guessan KF, Nanga YZ, Loukou YG and Dje KM. (2008). Evaluation of organic acids and sugars contents during the production of tchapalo, a traditional sorghum beer in Côte d'Ivoire. Journal of Food Technology, 6(5), 189-195.

[2] N'guessan KF, Aka S, Djeni NT and Dje KM. (2008). Effect of traditional starter inoculation rate on sorghum beer quality. Journal of Food Technology, 6 (6), 271-277.

[3] Dje KM, Aka S, Nanga YZ, Yao KC and Loukou YG. (2009). Predominant lactic acid bacteria involved in the spontaneous fermentation step of tchapalo process, a traditional sorghum beer of Côte d'Ivoire. Research Journal of Biological Sciences, 4 (7), 789-795.

[4] Kouame KB, Koko AC, Masse D and Assidjo NE. (2015). Batch fermentation process of sorghum wort modeling by artificial neural network. European Science Journal, 11, 75-93.

[5] Amane DN, Kouamé KB, Kouamé C and Assidjo EN. (2012). Optimisation du procédé de fabrication du tchapalo, bière traditionnelle ivoirienne par le plan factoriel fractionné. Afrique Science, 8(3), 69-81.

[6] Aka S, Fokou G, Doumbia M, Ahoussi JMS, Dje MK and Bonfoh B. (2017). Production et consommation du tchapalo à Abidjan: typologie des brasseuses et des consommateurs. European Scientific Journal, 13(1), 148-163.

[7] Holzapfel WH. (2002). Appropriate starter culture technologies for small- scale fermentation in developing countries. International Journal of Food Microbiology. 75, 197 -212.

[8] Aka-Gbezo S, N'Guessan KF, Yapo AE, Dje KM and Bonfoh B. (2015). Antibacterial and probiotic properties of lactic acid bacteria from traditional sorghum beer production in Côte d'Ivoire. International Journal of Advances in Pharmacy, Biology and Chemistry, 4(1), 103-113.

[9] N'guessan KF, N'dri YD, Camara F and Dje KM. (2010). Saccharomyces cerevisiae and Candida tropicalis as starter cultures for the alcoholic fermentation of tchapalo, a traditional sorghum beer. World Journal of Microbiology and Biotechnology, 26 (4), 693-699.

[10] Ayad EHE, Nashat S, El-Sadek N, Metwaly H and El-Soda M. (2004). Selection of wild lactic acid bacteria isolated from traditional Egyptian dairy products according to production and technological criteria. Food Microbiology, 21, 715-725.

[11] Arici M, Bilgin B, Sagdic O and Ozdemir C. (2004).Some characteristics of Lactobacillus isolates from infant faeces. Food Microbiology 21 (1), 19-24.

[12] Soro-Yao AA, Aka S, Thonart P and Dje KM. (2014). Assessment of the potential of lactic acid bacteria as dried starter culture for cereal fermentation. The Open Biotechnology Journal, 8, 1-5.

[13] Mukisa IM, Ntaate D and Byakika S. (2017). Application of starter cultures in the production of Enturire - a traditional sorghum-based alcoholic beverage. Food Science and nutrition, 5, 609-616.

[14] Apaliya MT, Kwaw E, Tchabo W, Sackey AS and Boateng NAS. (2017).The use of lactic acid bacteria as starter culture and its effect on the proximate composition and sensory acceptability of millet beverage. International Journal of Innovative Food Science and Technology, 1, 1-8.

[15] Olaoye OA, Ndife J and Raymond VI. (2017). Use of Lactobacillus plantarum as starter culture and its influence on physicochemical, microbiological and sensory characteristics of kunnu-aya produced from sorghum and tigernut. Journal of Food Quality, 1-8.

[16] Hassen Y, Mukisa IM, Kurabachew H and Desalegn BB. (2018). Evaluation of east and lactic acid bacteria starter cultures for the production of rice injera. Food Processing and Technology, 9(3), 1-5.

[17] Sawadogo-Lingani H, Diawara B, Traore AS and Jakobsen M. (2008). Technological properties of Lactobacillus fermentum involved in the processing of dolo and pito, West African sorghum beers, for the selection of starter cultures. Journal of Applied Microbiology, 104(3), 873-82.

[18] Mugula JK, Narvhus JA and Sørhaug T. (2003). Use of starter cultures of lactic acid bacteria and yeasts in the preparation of togwa, a Tanzanian fermented food. International Journal of Food Microbiology, 83, 307-318.

[19] Muyanja CMBK, Langsrud T and Narvhus JA. (2004). The use of starter cultures in the fermentation of bushera: a Ugandan traditional fermented sorghum beverage. Uganda Journal of Agricultural Sciences, 9, 606-616. 
[20] Agarry 00, Nkama I and Akoma O. (2010). Production of Kunun-zaki (A Nigerian fermented cereal beverage) using starter culture. International Research Journal of Microbiology, 1(2), 018-025.

[21] Vieira-Dalodé G, Madodé YE, Hounhouigan J, Jespersen L and Jakobsen M. (2008). Use of starter cultures of lactic acid bacteria and yeasts as inoculum enrichment for the production of gowé, a sour beverage from Benin. African Journal of Microbiology Research, 2, 179-186.

[22] Sawadogo-Lingani H, Lei V, Diawara B, Nielsen DS, Møller PL, Traoré AS and Jakobsen M. (2007). The biodiversity of predominant lactic acid bacteria in dolo and pito wort for the production of sorghum beer. Journal of Applied Microbiology, 103(4), 765-777.

[23] Maoura N, Mbaiguinam M, Gaillardin C and Pourquie J. (2006). Suivi technique, analytique et microbiologique de la bili bili, bière traditionnelle tchadienne. Afrique Science, 20(1), 69-82.

[24] Dje KM, N'guessan KF, Djeni NT and Dadie AT. (2008). Biochemical changes during alcoholic fermentation in the production of tchapalo, a traditional sorghum beer. International Journal of Food Engineering, 4 (7), 2.

[25] Akabanda F, Kwarteng JO, Tano-Debrah K, Parkouda C and Jespersen L. (2014). The use of lactic acid bacteria starter culture in the production of nunu, a spontaneously fermented milk product in Ghana. International Journal of Food Science, 1-11.

[26] Byakika S, Mukisa IM, Mugabi R and Muyanja C. (2019). Antimicrobial activity of lactic acid bacteria starters against acid tolerant, antibiotic resistant, and potentially virulent E. coli isolated from a fermented sorghummillet beverage. International Journal of Microbiology, 1-10.

[27] Velićanski AS, Cvetković DD, Markov SL, Šaponjac VTT and Vulić JJ. (2014). Antioxidant and antibacterial activity of the beverage obtained by fermentation of sweetened lemon balm (melissa offi cinalis l.) tea with symbiotic consortium of bacteria and yeasts. Food Technology and Biotechnology, 52 (4), 420-429.

[28] Detha AIR and Datta FU. (2016). Antimicrobial activity of traditional wines (Sopi and Moke) against Salmonella sp. and Escherichia coli. Journal of Advanced Veterinary and Animal Research, 3(3), 282-285.

\section{How to cite this article}

Aka S, Tano BM Kouakou-Kouamé AC and Koussemon-Camara M. (2020). Evaluation of potential lactic acid bacteria single starter cultures for production of traditional Ivoirian cereal beverages. GSC Biological and Pharmaceutical Sciences, 6(2), 182-195. 